\title{
High School Students' Perceptions about Biology, Related Influence of Factors and Players
}

\author{
Angeles Dominguez ${ }^{1,2}$, Itzel Hernandez ${ }^{1}$ and Jesus Beltran-Sanchez ${ }^{1}$ \\ Tecnologico de Monterrey, angeles.dominguez@tec.mx, armenta.itz@gmail.com, jbeltrans@tec.mx \\ Universidad Andres Bello, Santiago, Chile
}

\begin{abstract}
Research about students' viewpoints regarding STEM fields mostly address two target groups: physics/mathematics/engineering areas and undergraduate students. The purpose of this paper is to explore 9th-grade students' perceptions about biology and some of the factors and players that influence them in pursuing an academic or professional career in these fields of knowledge. A 13-item survey graded on a 5point Likert scale was administered to 350 Mexican students from two states, Chiapas and Nuevo Leon, as part of a broad research project that aims to determine which factors and players influence the perceptions of teenagers, from a gender perspective, about STEM fields. Results show statistically significant differences among group participants in the perceptions of the value of biology to their academic futures (T-Test, $p=0.035$ ) between genders in the state of Nuevo Leon (T-Test, $p=0.037,0.083$ ). Results also show significant correlation between parents' levels of education and students' selfefficacy (Pearson correlations). Conclusions drawn from this paper discuss the relatedness of teenagers' STEM perceptions and their academic and professional futures with respect to gender, geographic residency, family and self-efficacy. The research also highlights the need for a profound comprehension of students appreciation for science, technology, engineering and mathematics.
\end{abstract}

Index Terms - Biology, Educational Innovation, Gender perspective, High school students, Self-efficacy, STEM perceptions

\section{INTRODUCTION}

Efforts to broaden accessibility and enrollment in academic and professional STEM fields have increased worldwide. These goals are thought to be a consequence of rising demand for experts in science, technology, engineering and mathematics in several contexts of employment [1] - [2] , causing an urgent need to boost youth participation in these academic areas by promoting initiatives to engage primary and secondary school students [3]. Such educational efforts and their resulting outcomes, along with studies about the understanding of perceptions, attitudes and contextual factors that may or may not influence students to pursue STEM-related careers, mark a complex and sinuous path to obtain the engagement, commitment and genuine enthusiasm of students in those fields of knowledge.
Previous research concerning the expected science career choices of teenage students in light of future job forecasts have shown connectedness to a mixture of aspects, such as their interests, experiences outside school, attitudes and opinions towards science and science school courses, and opinions about present world environmental challenges [4]. These are considerations associated not only with school-related matters but also with a holistic and diverse understanding of the students' human development. Moreover, studies specifically related to students' perceptions and attitudes about STEM suggest important inclusiveness issues, highlighting that "all groups of students must receive equal chances of successful participation, especially those who continue to be underrepresented," $[3, \mathrm{p}$. 58]. This prompts researchers to use the lens filters of gender analysis and other specific sociocultural aspects.

Such perspectives seek to reveal the connectedness of career interests in STEM fields to pupils' attitudes, the role of differences across middle and high school grade levels and the gender and socioeconomic statuses of students [5]. Expectations to major in STEM or to select a distinct STEM major may also be related to perceptions of the social relevance of science [1] as well as self-efficacy awareness, [3] as shown in studies involving underrepresented minorities and gender [6]-[7]. Thus, this kind of research documents students' perceptions across a wide diversity of students, including the pre-university student population, about many aspects of STEM-related knowledge [8] other than the most studied landscapes of physics, mathematics and engineering [2].

To contribute to the understanding from the lessexplored perspectives mentioned above, authors of this paper present findings from an ongoing research project which aims to determine some of the factors and players that influence teenagers (13 to 15-years old) to build certain perceptions about science and technology from a gender perspective. Data obtained from the implementation of a 5 point-Likert-scale survey regarding the perception of 9th grade Mexican students about STEM school subjects are analyzed in the present work. This report targets attitudes, beliefs, perceptions and expectations of biology students about their professional and academic futures; it includes an examination of their reported interest and self-efficacy in this field and a possible linkage with their parents' levels of education.

Particularly, conclusions drawn from perceptions about 
knowledge acquired in biology classes are of singular relevance for the main research project, which analyzes perceptions of the five STEM-related subjects in the secondary-school (7th to 9th grade) Mexican curriculum; namely, mathematics, physics, chemistry, computer science and biology. This last subject is of great interest as it "has been known to continuously record low student enrollment, low interest and poor achievement levels," [9, p. 44], apart from the importance stemming from its integration and involvement in all the natural life sciences. Other studies have focused on relating perceptions about biology to handson experiences in school laboratories [10] and have compared interest in biotechnology topics between students enrolled in a biology class and others who may not be familiar with this subject [11]. However, this article provides a description and analysis of general perceptions of high school students about their biology classes with respect to their professional and academic futures.

The central objective of this report is to study high school students' perceptions about biology as well as some of the factors and players that influence them to continue an academic career or to seek a professional job in that area, professional and academic future perceptions and relationship between parents' level of education and reported self-efficacy. Differences are studied by state and by gender.

\section{RESEARCH METHODOLOGY}

\section{Sample}

For the purpose of this article, the responses of 350 9thgrade students enrolled in ten different secondary schools were used. Five of these schools are located in the state of Nuevo Leon, in Mexico's northeast region ( $\mathrm{n}=235$ ), and five others are in the state of Chiapas in Mexico's south region $(n=115)$. Those states were selected because of their contrasts in demography. Despite their similarities in total local population, territorial extension and male/female gender ratios, Nuevo Leon and Chiapas drastically differ in economic growth, level of education of people over the age of 15 and percentage of indigenous speaking population, as illustrated in Table I. For this reason, in each state, the school sample was selected by socioeconomic status to include urban and rural schools in combination with the level of marginalization (low and high).

\section{TABLE I}

CONTRASTING DEMOGRAPHIC FEATURES OF STUDIED MEXICAN STATES

\begin{tabular}{lll}
\hline Demographic feature & Nuevo Leon & Chiapas \\
\hline Population & $4,653,458$ & $4,796,580$ \\
Territorial extension & $64,156 \mathrm{~km}^{2}$ & $73,311 \mathrm{~km}^{2}$ \\
Contribution to national GDP & $7.5 \%$ & $1.9 \%$ \\
Men for every 100 women & 98.6 & 94.6 \\
Percentage of Urban - Rural & $95 \%-5 \%$ & $49 \%-51 \%$ \\
population & & \\
Level of education of people & 9.8 years & 6.7 years \\
over the age of 15 (years & Men 10 years & Men 7.1 years \\
studying) & Women 9.6 years & Women 6.3 years \\
$\begin{array}{l}\text { Percentage of indigenous } \\
\text { speaking population over the }\end{array}$ & $1 \%$ & $27 \%$ \\
age of 5 & & \\
\hline
\end{tabular}

On one hand, Chiapas' participant students report an average age of $13.9(\mathrm{SD}=0.70)$ years, of which $56(48.7 \%)$ are women and $59(51.3 \%)$ are male. On the other hand, 123 of Nuevo Leon's participants are women (52.3\%) and 110 (46.8\%) male, both reporting an average age of 14.56 $(\mathrm{SD}=0.57)$ years.

\section{Hypotheses}

To fulfil proposed objective, the following null hypotheses are stated:

Professional and academic future perceptions about biology of both states

$\mathrm{H}_{0 \mathrm{Al}}$ : The difference between the mean and the comparison value for professional future perceptions about biology of both states is equal to zero.

$\mathrm{H}_{0 \mathrm{~A} 2}$ : The difference between the mean and the comparison value for academic future perceptions about biology of both states is equal to zero.

Professional and academic future perceptions about biology of each state and gender

$\mathrm{H}_{0 \mathrm{~B} 1}$ : The difference between the mean and the comparison value for professional future perceptions about biology of Chiapas' males and females is equal to zero.

$\mathrm{H}_{0 \mathrm{~B} 2}$ : The difference between the mean and the comparison value for academic future perceptions about biology of Chiapas' males and females is equal to zero.

$\mathrm{H}_{0 \mathrm{Cl}}$ : The difference between the mean and the comparison value for professional future perceptions about biology of Nuevo Leon's males and females is equal to zero.

$\mathrm{H}_{0 \mathrm{C} 2}$ : The difference between the mean and the comparison value for academic future perceptions about biology of Nuevo Leon's males and females is equal to zero.

Relationship between parents' level of education and reported self-efficacy in biology for each state and gender

$\mathrm{H}_{0 \mathrm{D} 1}$ : There is no statistically significant relationship between Chiapas' mothers' level of education and reported self-efficacy in biology.

$\mathrm{H}_{0 \mathrm{D} 2}$ : There is no statistically significant relationship between Chiapas' fathers' level of education and reported self-efficacy in biology.

$\mathrm{H}_{0 \mathrm{E} 1}$ : There is no statistically significant relationship between Nuevo Leon's mothers' level of education and reported self-efficacy in biology. 
$\mathrm{H}_{\mathrm{OE} 2}$ : There is no statistically significant relationship between Nuevo Leon's fathers' level of education and reported self-efficacy in biology.

In section $I V$. Analysis, how these hypotheses were tested is addressed.

\section{Instrument}

A survey containing 52 items was administered to all participating students. It was designed to gather information about their perception of STEM school subjects and the influence of factors and players upon them in selecting these subjects for their future professional development and occupations. For this particular article, a selected section of 13 items graded on a 5-point Likert scale are reported. The first three selected items relate to self-efficacy and students' interests and were adapted from a validated survey [12]. The other ten selected statements were adapted for high school students from a survey used to assess the perceptions of engineering students about physics and mathematics [13] [14]. Each item was designed to ascertain their perceptions of each of the five STEM school subjects; namely, mathematics, physics, chemistry, computer science and biology. For this work, only answers for the subject of biology were analyzed. The items presented in this article are shown in Table II.

TABLE II

THIRTEEN STATEMENTS FOR THE ASSESSMENT OF SELF-EFFICACY, INTEREST AND PERCEIVED RELEVANCE OF BIOLOGY IN STUDENTS' ACADEMIC AND PROFESSIONAL FUTURES

\# Statement about biology

1 I am very good at biology.

2 My interest in biology is an important part that identifies me.

3 In biology class, my grades are better than those of my classmates.

4 I can see how the biology skills that I am currently developing will be useful in my professional career.

5 The ways of thinking being taught to me in biology will remain with me long after I graduate.

6 Biology classes are needed for other courses in my future studies.

7 Biology classes expose me to ideas which I know I will need later in my future studies.

8 I feel that the biology course I am currently taking teaches me how to formulate and solve problems that are directly related to my future studies.

$9 \quad$ I see being able to communicate effectively using biology arguments I am taught as an important skill to have.

10 The formal and rigorous aspects that I have learned in biology classes are important for my future professional career.

It is important to learn biology to find a better job.

12 For me, in biology, I only want to learn what I feel is likely to be assessed.

13 At some stage during my studies, I have been so overwhelmed by the biology classes that I have considered not studying a career in that area.

\section{Analysis}

In order to determine statistical significance in findings related to dependence or independence among participants' responses in the two groups, by gender or by region (state of Chiapas or Nuevo Leon), hypothesis t-tests were chosen [15]. To that end, the "Cohen d" (d) index was used to determine the effect size, as a way to identify the strength of the conclusions about group differences or about the relationship among variables, alongside the correct degrees of freedom $(\mathrm{df}=\mathrm{n}-1)$ which "establish the number of scores in a sample that are independent and free to vary because the sample mean places a restriction on sample variability" ( $p$. 190) [15].

Pearson correlations were also used for detecting correlation among variables, along with its direction of association [16], needed for the understanding of linkage between perceived self-efficacy and parents' levels of education. Both statistical proofs must fulfill certain assumptions [17] that our data satisfied.

- Normal distribution of scores: this requirement was assessed with a symmetry and kurtosis analysis obtaining values around \pm 2 .

- Interval level measurements: as a Likert scale was used in data collection instruments, continuous variables were involved.

- Variance homogeneity: a Levene proof was made to determine this requirement.

- Hypothesis rejectance: To set a typical probability level for rejecting the null hypotheses a value of alpha $=0.05$ is chosen. Knowing that the " $p$ value $(p)$ is the probability (p) that a result could have been produced by chance if the null hypothesis were true" (p. 189) [15], then $p$ values lower than $p=0.05$ are expected in order to decide hypothesis rejection.

\section{RESULTS}

The results indicate that students' perceptions remain close to the theoretical mean. Chiapas students have slightly higher expectations for the professional and academic future to pursue studies in biology. Regarding both perceptions, only for the academic future was there found a statistically significant difference $(p<.05)$ between the participants of the two states (Table III).

TABLE III

DIFFERENCES IN PERCEPTIONS BETWEEN STUDENTS FROM CHIAPAS AND NUEVO LEON REGARDING THE CONTRIBUTION OF BIOLOGY TO THEIR

\begin{tabular}{|c|c|c|c|c|c|c|c|}
\hline \multirow[t]{2}{*}{ Perception } & \multicolumn{2}{|c|}{ Chiapas } & \multicolumn{2}{|c|}{ Nuevo Leon } & \multirow[t]{2}{*}{$t(d f)$} & \multirow[t]{2}{*}{$p$} & \multirow[t]{2}{*}{$d$} \\
\hline & $\bar{X}$ & SD & $\bar{X}$ & SD & & & \\
\hline $\begin{array}{l}\text { Professional } \\
\text { future }\end{array}$ & 3.29 & 0.92 & 3.13 & 0.86 & $1.57(348)$ & 0.116 & 0.17 \\
\hline $\begin{array}{l}\text { Academic } \\
\text { future }\end{array}$ & 3.45 & 0.96 & 3.23 & 0.89 & $2.11(348)$ & 0.035 & 0.23 \\
\hline
\end{tabular}

Analyzing by gender, differences between men and women are investigated regarding the perceived contribution of biology for both the academic and professional future. In general, women report higher expectations than men to continue an academic and professional career, even though, in general, all values are close to the theoretical mean (3). 
Statistically significant differences are found in the professional future perspective (Table IV).

\section{TABLE IV}

GENDER DIFFERENCES REGARDING THE CONTRIBUTION OF BIOLOGY IN THEIR ACADEMIC AND PROFESSIONAL FUTURE, BY STATE (T-TEST, $p<0.05$ )

\begin{tabular}{llllll}
\hline State & Perception & Women & Men & $t(d f)$ & $p$
\end{tabular}

\begin{tabular}{llllllllll}
\hline Chiapas & $\begin{array}{l}\text { Professional } \\
\text { future }\end{array}$ & 3.44 & 0.87 & 3.15 & 0.96 & $1.68(113)$ & 0.095 & 0.31 \\
& $\begin{array}{l}\text { Academic } \\
\text { future }\end{array}$ & 3.61 & 0.89 & 3.31 & 1.00 & $1.69(113)$ & 0.093 & 0.35 \\
$\begin{array}{l}\text { Nuevo } \\
\text { Leon }\end{array}$ & $\begin{array}{l}\text { Professional } \\
\text { future }\end{array}$ & 3.24 & 0.79 & 3.00 & 0.91 & $2.10(233)$ & 0.037 & 0.28 \\
& $\begin{array}{l}\text { Academic } \\
\text { future }\end{array}$ & 3.33 & 0.85 & 3.12 & 0.93 & $1.74(233)$ & 0.083 & 0.23 \\
\end{tabular}

$t=$ statistic T, $d f=$ degrees of freedom, $p=$ significance, Cohen's $d=$ effect size

By analyzing the school levels of the fathers and mothers of the participants, it is possible to note that men achieve higher levels of education than women, a situation that occurs in both states. It is observed that the parents belonging to the state of Nuevo Leon obtain a higher academic level. That accentuates by gender in the state of Chiapas (Table V). In Mexico, high school was recently included as mandatory education. For this report, we refer to basic education as elementary and middle school (1st to 9 th grade); pre-college includes grades 10th to 12 th and university refers to undergraduate and graduate degrees.

TABLE V

SCHOOL LEVEL OF PARENTS OF THE PARTICIPANTS BY STATE, CHIAPAS AND NUEVO LEON: 346 MOTHERS AND 341 FATHERS

\begin{tabular}{llcccc}
\hline State & School level & \multicolumn{2}{c}{ Women } & \multicolumn{2}{c}{ Men } \\
& & $\mathrm{n}$ & $\%$ & $\mathrm{n}$ & $\%$ \\
\hline Chiapas & None & 6 & 5.2 & 10 & 8.5 \\
& Basic school & 76 & 66.1 & 57 & 49.6 \\
& Pre-college level & 27 & 23.5 & 30 & 26.1 \\
& University level & 6 & 5.1 & 16 & 13.9 \\
Nuevo & None & & & & \\
Leon & Basic school & 112 & 47.7 & 96 & 40.9 \\
& Pre-college level & 55 & 23.4 & 64 & 27.2 \\
& University level & 64 & 27.3 & 66 & 28.2 \\
& & & & & \\
\hline \multicolumn{2}{c}{$\mathrm{n}=$ sample size, \%=percentage } & & & &
\end{tabular}

Moreover, the parents' school levels with respect to the students' perceptions towards biology has been analyzed by region and by gender of the students. In the state of Chiapas, the schooling of both parents is positively associated with the perception that their daughters have regarding their competence in biology. Also, that perception is associated with the contribution that biology has towards their academic and professional futures (Table VI).

TABLE VI

ASSOCIATION BETWEEN CHIAPAS' PARENT'S LEVEL OF EDUCATION AND STUDENT'S SELF-EFFICACY (PEARSON CORRELATION, $p<0.05$ )*

\begin{tabular}{llllll}
\hline Gender & Variables & 1 & 2 & 3 & 4 \\
\hline
\end{tabular}

\begin{tabular}{|c|c|c|c|c|c|}
\hline \multirow{6}{*}{$\begin{array}{l}\text { Female } \\
(\mathrm{n}=55)\end{array}$} & School level of mother & 0.201 & $0.340^{*}$ & $0.267 *$ & $0.297 *$ \\
\hline & School level of father & 0.152 & $0.279 *$ & 0.197 & $0.293 *$ \\
\hline & 1. I am very good at biology. & - & $0.668 *$ & $0.474 *$ & $0.389 *$ \\
\hline & $\begin{array}{l}\text { 2. In biology class, my grades } \\
\text { are better than those of my } \\
\text { classmates. }\end{array}$ & & - & $0.513^{*}$ & $0.415^{*}$ \\
\hline & $\begin{array}{l}\text { 3. Contribution of biology to } \\
\text { my professional future }\end{array}$ & & & - & $0.782 *$ \\
\hline & $\begin{array}{l}\text { 4. Contribution of biology to } \\
\text { my academic future }\end{array}$ & & & & - \\
\hline \multirow{6}{*}{$\begin{array}{l}\text { Male } \\
(n=59)\end{array}$} & School level of mother & $0.319 *$ & 0.239 & 0.182 & 0.184 \\
\hline & School level of father & $0.324^{*}$ & 0.195 & 0.248 & $0.299 *$ \\
\hline & 1. I am very good at biology. & - & $0.729 *$ & $0.363^{*}$ & $0.312^{*}$ \\
\hline & $\begin{array}{l}\text { 2. In biology class, my grades } \\
\text { are better than those of my } \\
\text { classmates. }\end{array}$ & & - & $0.515^{*}$ & $0.460 *$ \\
\hline & $\begin{array}{l}\text { 3. Contribution of biology to } \\
\text { my professional future }\end{array}$ & & & - & $0.875^{*}$ \\
\hline & $\begin{array}{l}\text { 4. Contribution of biology to } \\
\text { my academic future }\end{array}$ & & & & - \\
\hline
\end{tabular}

On one hand, in the case of male students, the schooling of parents cannot be associated with the other mentioned variables. However, it is important to remember that the perception that men have of their competence in biology is also associated with their academic and professional expectations (Table VI).

On the other hand, for the participants from the state of Nuevo Leon, there was found a positive correlation between self-reported competence by students and the future contribution of biology in their academic and professional lives. With regards to the association of the schooling of fathers and mothers, this is positively associated with the results of men; however, no relationship was found in the women's data. Also, it was found that the parent's schooling is positively associated to the result of male students, but no correlation was found for the female students (Table VII).

\section{TABLE VII}

ASSOCIATION BETWEEN NUEVO LEON'S PARENT'S LEVEL OF EDUCATION AND STUDENT'S SELF-EFFICACY (PEARSON CORRELATION, $p<0.05$ )*

\begin{tabular}{|c|c|c|c|c|c|}
\hline Gender & Variables & 1 & 2 & 3 & 4 \\
\hline \multirow{6}{*}{$\begin{array}{l}\text { Female } \\
(\mathrm{n}=122)\end{array}$} & School level of mother & -.052 & -.060 & 0.080 & -.038 \\
\hline & School level of father & -.107 & -.097 & 0.123 & 0.088 \\
\hline & 1. I am very good at biology. & - & $0.524 *$ & $0.308^{*}$ & $0.316^{*}$ \\
\hline & $\begin{array}{l}\text { 2. In biology class, my grades } \\
\text { are better than those of my } \\
\text { classmates. }\end{array}$ & & - & $0.328^{*}$ & $0.279^{*}$ \\
\hline & $\begin{array}{l}\text { 3. Contribution of biology to } \\
\text { my professional future }\end{array}$ & & & - & $0.851^{*}$ \\
\hline & $\begin{array}{l}\text { 4. Contribution of biology to } \\
\text { my academic future }\end{array}$ & & & & - \\
\hline \multirow{6}{*}{$\begin{array}{l}\text { Male } \\
(\mathrm{n}=108)\end{array}$} & School level of mother & $0.304 *$ & 0.176 & $0.316^{*}$ & $0.199 *$ \\
\hline & Schoo & $0.416^{*}$ & $0.289^{*}$ & $0.203^{*}$ & $0.237 *$ \\
\hline & 1. I am very good at biology. & . & $0.665^{*}$ & $0.590 *$ & $0.599 *$ \\
\hline & $\begin{array}{l}\text { 2. In biology class, my grades } \\
\text { are better than those of my } \\
\text { classmates. }\end{array}$ & & - & $0.402 *$ & $0.404^{*}$ \\
\hline & $\begin{array}{l}\text { 3. Contribution of biology to } \\
\text { my professional future }\end{array}$ & & & - & $0.836^{*}$ \\
\hline & $\begin{array}{l}\text { 4. Contribution of biology to } \\
\text { my academic future }\end{array}$ & & & & - \\
\hline
\end{tabular}

\section{DISCUSSION}


The chosen statistical proofs used in the analyses of the 13items surveyed allow the understanding of results in diverse dimensions of inquiry such as gender, students' states of residency (region), their perceived self-efficacy and the parents' levels of education. Aligned with these aspects, three main findings are selected by the authors for their relevance and contributions to the research literature previously presented.

\section{Students in Chiapas find biology more valuable for their academic future than the students in Nuevo Leon.}

When comparing student perceptions about the value of biology to their academic futures, students in Chiapas report a statistically-significant higher perception of biology (Ttest, $\mathrm{p}$-value $=0.035$ ) over the students in Nuevo Leon as shown in Table III. Thus, hypothesis $\mathrm{H}_{0 \mathrm{~A} 2}$ is rejected. This outcome complements the findings of [5], as they conducted their research uniquely with low socioeconomic status students, finding that 'according to the students' responses, the life sciences area was predominant among low socioeconomic status students who stated desire for STEMrelated occupations," [5, p. 69]. In our research, socioeconomic conditions between Chiapas and Nuevo Leon are of great contrast, demographically denoting Chiapas as a low-socioeconomic-status state. Considering biology part of the "life sciences area", the results are consistent.

Furthermore, differences between male and female perceptions of biology in Chiapas were not statistically significant, just as previously reported also by [5]: "students' socioeconomic statuses may be another reason for similarities between males and females in STEM career interest," [5, p. 68]; thus, the students of said contexts, no matter their gender, may think of STEM fields as financially stable.

II. Nuevo Leon's females find biology more valuable for their professional futures than Nuevo Leon's males.

When comparing perceptions between female and male students (Table IV) only in Nuevo Leon about the value of biology to their professional futures, statistically significant differences are also found (T-test, $\mathrm{p}=0.037$ ), which implies that only hypothesis $\mathrm{H}_{0 \mathrm{C} 1}$ is rejected. Studies from $\mathrm{Abu}$ Dhabi [4] and Japan [7] report gender differences "especially the popularity of biology among females," [7, p. 427]. On one hand, this may be explained because of outside-of-school activities. When children are exposed to extracurricular activities, girls have shown to have a preference for biology compared to a predilection towards physics by the males $[4, \mathrm{p}$. 5]. In the case of our research sample, part of the survey also assessed previous extracurricular experiences in science and found that Nuevo Leon's students were more likely to be exposed to this kind of science stimulation.

\section{Self-efficacy and students' perceptions of biology}

Findings relative to students' perceived self-efficacy in biology correlated with the parents' levels of education
(Pearson correlations, ${ }^{*} \mathrm{p}<0.05$ ) in the female responses in Chiapas (Table VI) and in the male responses in Nuevo Leon (Table VII). Results also showed that for the whole sample, perceptions of self-efficacy were associated with a better appreciation of biology for the development of academic and professional futures, then hypotheses $\mathrm{H}_{0 \mathrm{D} 1}$, $\mathrm{H}_{0 \mathrm{D} 2}, \mathrm{H}_{0 \mathrm{E} 1}$ and $\mathrm{H}_{0 \mathrm{E} 2}$ are rejected.

Generally speaking, it has been reported that "the attitude that students have of themselves in science and mathematics is related to their school experience" [8, p. 2] and that "personal perceptions and confidence in abilities and levels of preparation impact the students' college choice process," [3, p. 59].

\section{CONCLUSIONS}

The association of students' self-reported competencies with a positive perception of biology in their prospective development, regardless of gender and residency, highlight the importance of self-efficacy and their perceptions of the influence of a particular STEM on their academic and professional futures. Yet, the relevance of the educational level of the father and the mother, as well as their residency, were shown to influence a student's aspirations. To improve parental educational background or to change place of residency are very complicated; however, through our educational institutions, we can involve parents in actions that widen the horizons of opportunities and applications of STEM careers for students, and we can debunk the myths and stereotypes about gender in the professions.

A deeper understanding of students' perceptions about biology and other sciences, technology, engineering and mathematics is a priority to develop resources that foster a positive view of those areas among young students. These efforts should have a common goal to promote gender equality; even more, to foster educational inclusion that recognizes and values differences, to potentialize participation and, possibly, to generate cultural shifts to fresh and favorable thoughts about the potential of STEM academic and professional pursuits, beginning from early childhood.

\section{ACKNOWLEDGMENTS}

This research was partially supported by CONACYTINMUJERES, Project 268261, entitled, "Determination of the Factors and Actors that Influence the Perception of Adolescents towards Science and Technology: A Gender Study." We also would like to acknowledge the financial and the technical support of Writing Lab, TecLabs, Tecnologico de Monterrey, Mexico, in the production of this work.

\section{REFERENCES}

[1] Blanchard Kyte, Sarah and Riegle-Crumb, Catherine. February 2017 "Perceptions of the Social Relevance of Science: Exploring the Implications for Gendered Patterns in Expectations of Majoring in STEM Fields.” Social Sciences 6(1), pp. 1 - 19. 
[2] Issapour, Marjaneh and Kelly, Angela M., March 2015. "How student gender, SAT score, and interest in science relate to performance in introductory engineering technology coursework." Proceedings of the 2015 IEEE Integrated STEM Education Conference, Princeton, NJ, USA, pp. $221-224$

[3] Alhaddab, Taghreed A. and Alnatheer, Suleman A., March 2015. "Future scientists: How women's and minorities' math self-efficacy and science perception affect their STEM major selection." Proceedings of the 2015 IEEE Integrated STEM Education Conference, Princeton, NJ, USA, pp. 58-63.

[4] Badri, Masood et al. December 2016. "My science class and expected career choices - a structural equation model of determinants involving Abu Dhabi high school students." International Journal of STEM Education 3(12), pp. $1-21$.

[5] Yerdelen, Sündüs, Kahraman, Nurcan and Tas, Yasemin. June 2016. "Low Socioeconomic Status Students' STEM Career Interests in Relation to Gender, Grade Level, and STEM Attitude." Journal of Turkish Science Education 13(Special Issue), pp. 59 - 74.

[6] Cheryan, Sapna et al. January 2017. "Why are some STEM fields more gender balanced than others?" Psychological Bulletin 143(1), pp. 1-35.

[7] Scantlebury, Kathryn et al. March 2007. "Avoiding the Issue of Gender in Japanese Science Education." International Journal of Science and Mathematics Education 5(3), pp. 415 - 438.

[8] Zavala, Genaro and Dominguez, Angeles. June 2018. "STEMoriented students' perception of the relevance of physics." Proceedings of the 125th ASEE Annual Conference and Exposition, Salt Lake City, UT, USA, pp. $1-20$.

[9] Nwafor, Chidozie E. and Oka, Obeten O. March 2018. "Secondary School Students' Interest Inventory in Biology." International Journal of Humanities Social Sciences and Education 5(3), pp. 44 - 59.

[10] Luketic, Christine D. and Dolan, Erin L. April 2013. "Factors influencing student perceptions of high-school science laboratory environments.” Learning Environments Research 16(1), pp. $37-47$.

[11] Fonseca, Maria J. et al. September 2012. "Multidimensional analysis of high-school students' perceptions about biotechnology." Journal of Biological Education 46(3), pp. 129 - 139.
[12] Porche, Michelle et al. June 2008. "Key Factors Related to High School Girls' Interest and Aspirations in Engineering, Science, and Math." Proceedings of the 2008 ASEE Annual Conference and Exposition, Pittsburgh, PA, USA, pp. 13.827.1 - 13.827.20.

[13] Zavala, Genaro et al. June 2015. "Students' perception of relevance of physics and mathematics of engineering" Proceedings of the 122th ASEE Annual Conference and Exposition, Seattle, WA, USA, pp. 26.1435.1 - 26.1435.22.

[14] Zavala, Genaro and Dominguez, Angeles. June 2016. "Engineering students' perception of relevance of physics and mathematics" Proceedings of the 123th ASEE Annual Conference and Exposition, New Orleans, LA, USA, pp. 26664.1 - 26664.20.

[15] Creswell, John W. 2011. Educational research: Planning, conducting, and evaluating quantitative and qualitative research, 4th ed., Boston: Pearson.

[16] Field, Andy. 2009. Discovering Statistics Using SPSS, 3rd ed., Thousand Oaks, CA: Sage Publications.

[17] Kerlinger, Fred N. 2002. Investigación del Comportamiento, 4th ed., Mexico: McGraw Hill.

\section{AUTHOR INFORMATION}

Angeles Dominguez, Professor, Associate Dean of Faculty Development at the School of Medicine and Health Science, Tecnologico de Monterrey, Monterrey, Mexico.

Professor-Researcher, Faculty of Engineering, Universidad Andres Bello, Santiago, Chile.

Itzel Hernandez, $\mathrm{PhD}$ student, Department of Education and Humanities, Tecnologico de Monterrey.

Jesus Beltran-Sanchez, Project Manager, School of Medicine and Health Sciences, Tecnologico de Monterrey. 